\title{
ANALYSIS OF CALCAREOUS SOILS FOR TWO VARIOUS FACIES WITHIN THE NATURE RESERVE OF EL-MERGUEB (M'SILA, ALGERIA)
}

\author{
SAMIR MEZANI ${ }^{1}$, AMINA ADJABI $\square^{2}$, HACHEMI SIDI², RABAH BOUNAR ${ }^{3}$, HAMID REZA NASERI ${ }^{4}$ \\ ${ }^{1}$ Faculty of Biological and Agricultural Sciences, University Mouloud Mammeri of Tizi Ouzou, Tizi Ouzou, Algeria; e-mail: samecolo@hotmail.fr \\ ${ }^{2}$ Laboratory of Research in Ecology and Environment (LREE), University Abderrahman Mira of Bejaia, Bejaia, Algeria; e-mail: adjabi_amina@yahoo.com, \\ shaokas@yahoo.fr \\ ${ }^{3}$ Department of Natural and Life Sciences, University Mohamed Boudiaf of M’sila, M'sila, Alegria; e-mail: bounar@univ-msila.dz \\ ${ }^{4}$ International Desert Research Center (IDRC) University of Tehran, Tehran, Islamic Republic of Iran; e-mail: hrnaseri@ut.ac.ir
}

$\bowtie$ Corresponding author

Received: 11 July 2021 / Accepted: 1 October 2021

\begin{abstract}
Mezani S., Adjabi A., Sidi H., Bounar R., Naseri H.R.: Analysis of calcareous soils for two various facies within the nature reserve of El-Mergueb (M’sila, Algeria). Ekológia (Bratislava), Vol. 40, No. 4, p. 337-347, 2021.

This research was conducted on the protected area of El-Mergueb at M'sila province. The zone of El-Mergueb is located about $180 \mathrm{~km}$ south of the capital Algiers, at an altitude from 550 to $800 \mathrm{~m}$, and is characterised by arid climate. The zone of El-Mergueb has a landscape from the steppe to Alfa that lies just as well in the flat ridges hills that in their slopes and in the top part of the ravines. Alfa tenacissima dominates the most geographical space of El-Mergueb. This study is based on the analysis of the homogenous and heterogeneous facies by the determination of the content of calcium carbonate $\left(\mathrm{CaCO}_{3}\right)$, active calcium carbonate (ACCE) and gypsum through monitoring these chemical parameters during 3 years: 2017, $2018,2019$. Six soil profiles of 15 soil samples collected in the site of study were studied and several chemical soil properties were considered. These factors included: soil pH, calcium carbonate $\left(\mathrm{CaCO}_{3}\right)$, active total carbonate $(\mathrm{CA})$, gypsum $\left(\mathrm{CaSO}_{4}\right)$ and electrical conductivity (EC). Principal component analysis (PCA) was used to identify the variations in soil properties. Results showed that there are significant relationships between some soil factors and two PCA axes. The results thus obtained showed that the content of $\mathrm{CaCO}_{3}$ and $\mathrm{CA}$ analysed ranged from average to high. The average of gypsum and salinity was low. Floristic diversity defined 284 species. The data on the chemical characteristics of the soil studied have been the subject of a detailed statistical analysis (PCA). Our database consisted of quantitative variables. The implementation of the PCA to the soils studied showed a major dominance of the limestone in the two stations, which explains the alkaline $\mathrm{pH}$ and the low concentration of gypsum. Finally, these types of high total limestone are the most observed in the majority of steppe and arid soils.
\end{abstract}

Key words: calcareous soils, Mediterranean soil, vegetation steppe, arid ecosystem, natural reserve of El-Mergueb.

\section{Introduction}

Changes in climate and land use induced by human activities affect productivity, water regime and biodiversity, and result in changes in the structure and functioning of terrestrial ecosystems. These alterations would probably intensify in the near future (Miranda et al., 2011). There is an extensive literature analysing the potential effects of increased greenhouse gas concentrations in the atmosphere on ecosystem function and services. However, an almost unexplored, but important characteristic of global change is the alteration of rainfall patterns, with probable increases in rainfall variability (IPCC, 2007). The United Nations Convention to Combat Desertification (UNCCD) defines arid, semi-arid and dry sub-humid zones as 'areas, other than polar and sub-polar regions, in which the ratio of annual precipitation to potential evapotranspiration falls within the range from 0.05 to 0.65 '. Hyper-arid zones are characterised by a ratio typically less than 0.05 . Together, these arid environments account for over $47 \%$ of the landmass of the earth and are spread geographically across all continents. The African continent contains the largest area of arid environments, while Australia has the highest proportion (about 75\%) of its area (Gratzfeld, 2003). Mediterranean ecosystems are especially sensitive to climate change because they have large topographic complexity with disparate land uses as well as marked water availability gradients (Lavorel et al., 1998). Mediterranean shrub land ecosystems are quite vulnerable to rising temperatures and reduced water availability (UsoDomenech et al., 1995), and the expected increase in aridity and temperatures in regions already dry, such as the Mediterranean basin, will likely have serious consequences (IPCC, 2007).

Mediterranean climates are characterised by winter rains with some months of excess rainfall over evapotranspiration, warm and dry summer months with moisture deficits drying out soils and their annual vegetation (xeric moisture regime). They are found on the western parts of all continents, between the cooler temperature zone and the hot dry desert zone. The largest

(c) The Author(s) 2021. This is an open access article distributed under the terms of the CC BY-NC-ND license.

https://content.sciendo.com/view/journals/eko/eko-overview.xml 
Mediterranean region, surrounding the Mediterranean Sea, extends over 4,300,000 $\mathrm{km}^{2}$ and exhibits a wide variety of soils and geo-ecosystems. Mediterranean soils are no longer used as a separate classification group in modern, well defined, soil propertycontrolled taxonomies (Soil Taxonomy; FAO system), but have been partially replaced by Duchaufour's term Fersiallitic soils in some classification systems. Terra rossa continues to be used in some classification for hard limestone-derived red soils, mostly shallow (Yaalon, 1999).

The Mediterranean region is one of the 34 hot spots of biodiversity identified at a global level. This richness is explained by the diversity of geological and edaphic contexts, by strong heterogeneity of the climatological conditions at meso- and micro-scale and by the seniority and importance of agro-pastoral practices. This region is subject to strong environmental pressures of different nature: climatic stresses (intense and prolonged droughts), poor soil conditions (thin, sandy, poor and xeric soils) and anthropogenic perturbations more and more intensely linked to the development of human populations. All the typical pressures of the Mediterranean regions are exacerbated in the semi-arid and arid North African environments. In Algeria, the degradation of natural resources remains a topical problem associated with climate change, deforestation and intensive pastoralism, soil erosion and the recurrence of fires (FAO, 2013). Arid soils possess unique characteristics that distinguish them from soils from more humid regions. Arid systems are generally limited in biological activity, and thus contain low levels of organic carbon. This lack of organic carbon is a large driver in the structuring and function of arid soils. Extended periods of water deficiencies also slow the elimination or leaching of soluble salts, which are further accumulated due to high rates of evaporation. Thus, arid soils tend to accumulate calcium carbonate, gypsum or silica. Despite similarities in soil genesis, the different climates, geology and vegetation of arid lands create unique soil characteristics, so that the morphology and soil characteristics vary between different dry lands. A characteristic of arid regions is reduced biological diversity (Steven, 2017). In fact, a global survey of dry lands worldwide found that the diversity of soil bacteria and fungi was linearly correlated to the aridity of the ecosystem (Maestre et al., 2016). In this regard, aridity is a large predictor of the diversity of soil communities. However, dry lands are not homogenous regions experiencing low precipitation. The vegetation is sparse, soil edaphic factors vary, the terrain is uneven, and precipitation and temperature vary erratically (Maestre, Cortina, 2002). The Algerian steppes constitute a geographical unit whose limits are defined by a bioclimatic criterion. With an estimated area of about 20 million ha, the Algerian steppes are located between the $400-\mathrm{mm}$ rainfall isohyet to the north and the $100 \mathrm{~mm}$-rainfall isohyet to the south, forming a 1000-km-long ribbon over a width of $300 \mathrm{~km}$ in the west and in the centre, reduced to less than $150 \mathrm{~km}$ in the east (Miara et al., 2018). According to Nedjraoui and Bédrani (2008), the steppe regions constitute a buffer between coastal Algeria and Saharian Algeria, of which they limit the negative climatic influences on the former.

Calcareous soils cover a large percentage of land from the north coastal region of Africa (Taalab et al., 2019). Calcareous soils are defined as soils containing large amounts of calcium carbonate, which affect distinctly the soil properties related to plant growth, whether they are physical, such as water rela- tions and soil crusting, or chemical, such as the availability of plant nutrients (Rasha, 2005). Carbonates, which are common constituents of many soils of arid and semi-arid areas, have a marked influence on soil chemical properties, for example, $\mathrm{pH}$, cation and anion sorption and physical properties, such as soil structure (Del Campillo et al., 1992).

Gypsum is widespread in both arid and semi-arid regions. Gypsum $\left(\mathrm{CaSO}_{4} \cdot 2 \mathrm{H}_{2} \mathrm{O}\right)$ is found over a wide range of temperatures, but most gypsic soils occur in xeric, ustic and aridic soil moisture regimes (FAO, 1990). Understanding the relationship between plant diversity and land use history can have important implications in management decisions, especially when these ecosystems were widely used by humans (Tálamo et al., 2012). The effects of environmental variables on plant species have been the subject of many ecological studies in recent years (Ramirez et al., 2007).

The first aim of this study was to identify the floristic composition of the two stations (homogenous and heterogeneous) of the experimental site. The second aim was to analyse the chemical typology of calcareous soils. Moreover, the study also aimed to obtain information about how can the calcareous soils impact the development of vegetation under an arid climate with low precipitation. The results can be used like an argument to explain how this category of ecosystem with homogenous and heterogeneous facies inside natural reserves in semi-arid and arid regions resists climatic changes and human impact; also, the results show the potential of the ecosystem's vulnerability to degradation. Finally, it was aimed to propose a new strategy to protect and preserve the biodiversity indicators of this ecosystem and similar type of ecosystem.

\section{Material and methods}

\section{Study site location and description}

The zone of El-Mergueb is a natural area of steppe that is to the western limit of the pan of the Hodna. It occupies an area of 16.481 ha 42 are and 67 that, and straddles three district steppes of the northern side of the Atlas of the Sahara belonging to the province of M'Sila (Hadjab et al., 2016). According to the law on 'protected areas in the framework of sustainable development' proposed in July 2005 to the General Secretariat of the Government by the Ministry of Spatial Planning and Environment (MATE), the natural site of El-Mergueb can only be classified in the category 'Habitat and Species Management Area' established by the IUCN (Plan de gestion..., 2005). The two experimental stations are between latitudes $\left(35^{\circ} 36^{\prime} 03.4^{\prime \prime} \mathrm{N}, 35^{\circ} 32^{\prime} 42.1^{\prime \prime} \mathrm{N}\right)$ and longitudes $\left(03^{\circ} 56^{\prime} 33.4^{\prime \prime} \mathrm{E}, 04^{\circ} 00^{\prime} 17.5^{\prime \prime} \mathrm{E}\right)$ with an altitude of 568 and $633 \mathrm{~m}$ and are located in the region of Ain El-Hadjel (Fig. 1).

The El-Mergueb reserve belongs to the structure of the high steppe plains formed by thick, more or less horizontal alluvial deposits accumulated on the primary base. The soils deposited in horizontal layers belong, from a geological point of view, to the more or less gypsum Miocene. They are covered locally by limestone banks of the lacustrine Pliocene. The relief of the reserve is little accentuated. The relative altitude does not exceed some metres. It is a plain of medium altitude that oscillates between 550 and $800 \mathrm{~m}$, whose average slope varies between 3 and $20 \%$. It is also a desert enclave in the highlands presenting a hilly relief (Ioualen, 2012). 


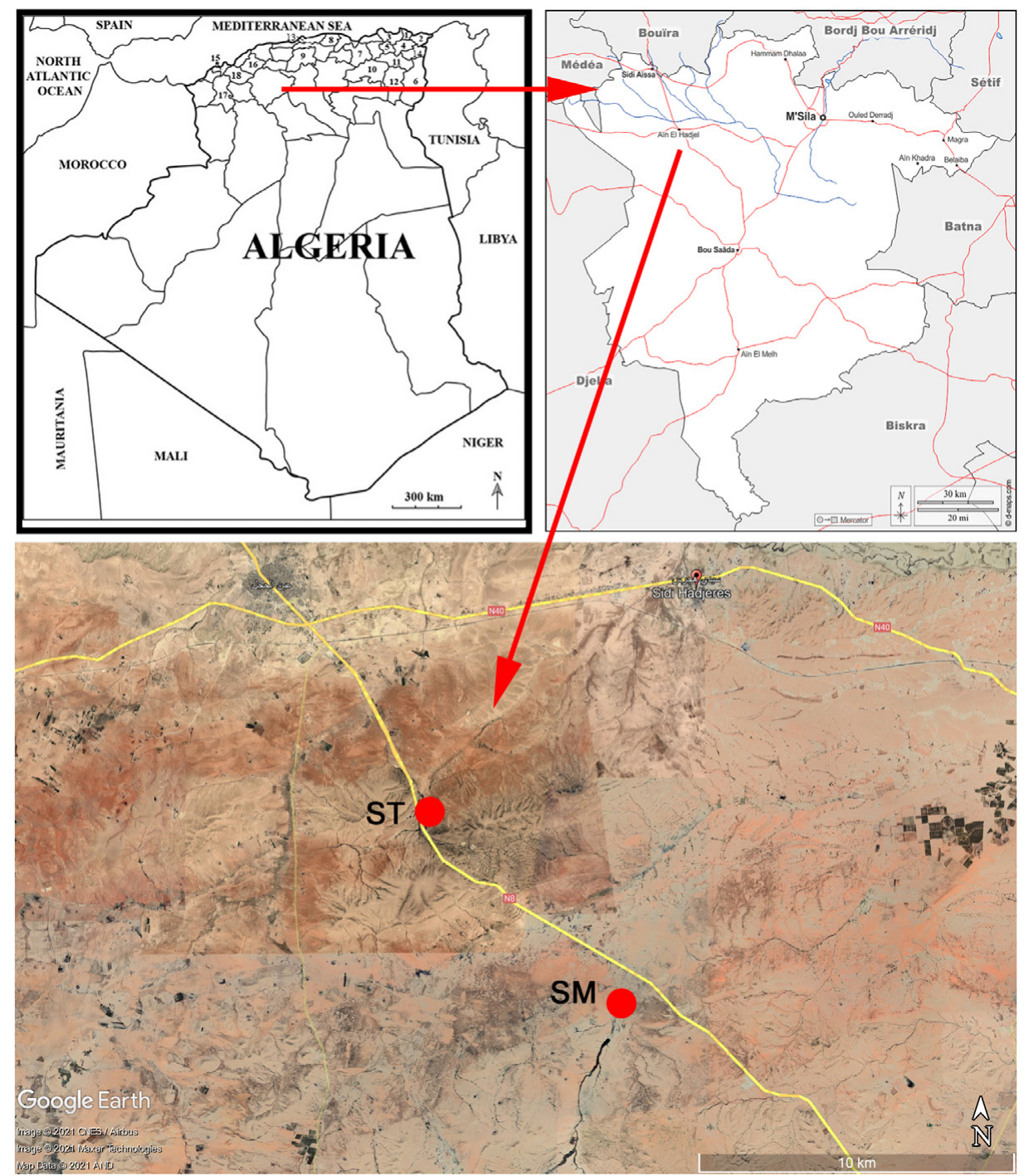

Fig. 1. The geographical position of the nature reserve of El-Mergueb with the location of the study area (Ain El-Hadjel) (Ghaouaci et al., 2018, Google Earth, d-maps.com).

\section{Vegetation study and identification}

This research was performed from April 2017 to May 2019. A survey was carried out by observation and sampling plants using the phytosociology method, the 'Braun-Blanquet approach'. Its principal goals are delimitation and characterisation of vegetation types based on the complete floristic (species) composition. Plots are placed to minimise within-plot heterogeneity and maximise between-plot variability; typical sizes are $4-25 \mathrm{~m}^{2}$ in herbaceous and $50-400 \mathrm{~m}^{2}$ in woody vegetation. Plot records consist of header data (locality, environment, structure) and a complete species list with cover values. Floristically similar concrete stands (phytocoenoses), places vegetation units into a hierarchical system based on varying degrees of floristic similarity (Dengler, 2017). The floristic data have been identified by an updated nomenclature of species according to the flora of Ozenda $(1958,1991 \mathrm{a}, \mathrm{b})$ and the New flora of Algeria by Quezel and Santa (1962-1963). Also, we calculated the frequencies of the dominant botanical group in each station.

\section{Description of facies}

The stations were selected based on the homogenous and heterogeneous floristic composition of each one with the dominant species and representative. This phase corresponds to an inventory of the flora, based on the execution of the floristic surveys. In general, realisation of the floristic surveys focused on ecological parameters, physiognomy and floristic homogeneity. Many authors have discussed how to carry out phytosociological surveys (Braun Blanquet et al., 1952; Kaabache, 1990). For each survey, the following are noted: geographical location and stationary characters (altitude, geological substrate, covers, etc.). The first station (Station $\mathrm{T}$ ) is a homogenous steppe formation dominated by Stipa tenacissima L. It is located between the geographical coordinates $03^{\circ} 56^{\prime} 33.4^{\prime \prime} \mathrm{E}$ and $35^{\circ} 36^{\prime} 03.4^{\prime \prime} \mathrm{N}$. The altitude is $633 \mathrm{~m}$ with a recovery rate of $20 \%$ (Fig. 2). The second station (Station $\mathrm{M}$ ) is a heterogeneous steppe represented by the groups of species of Artemisia campestris L. and Medicago arborea L. It occupies the geographical coordinates $04^{\circ} 00^{\prime} 17.5^{\prime \prime} \mathrm{E}$ and 

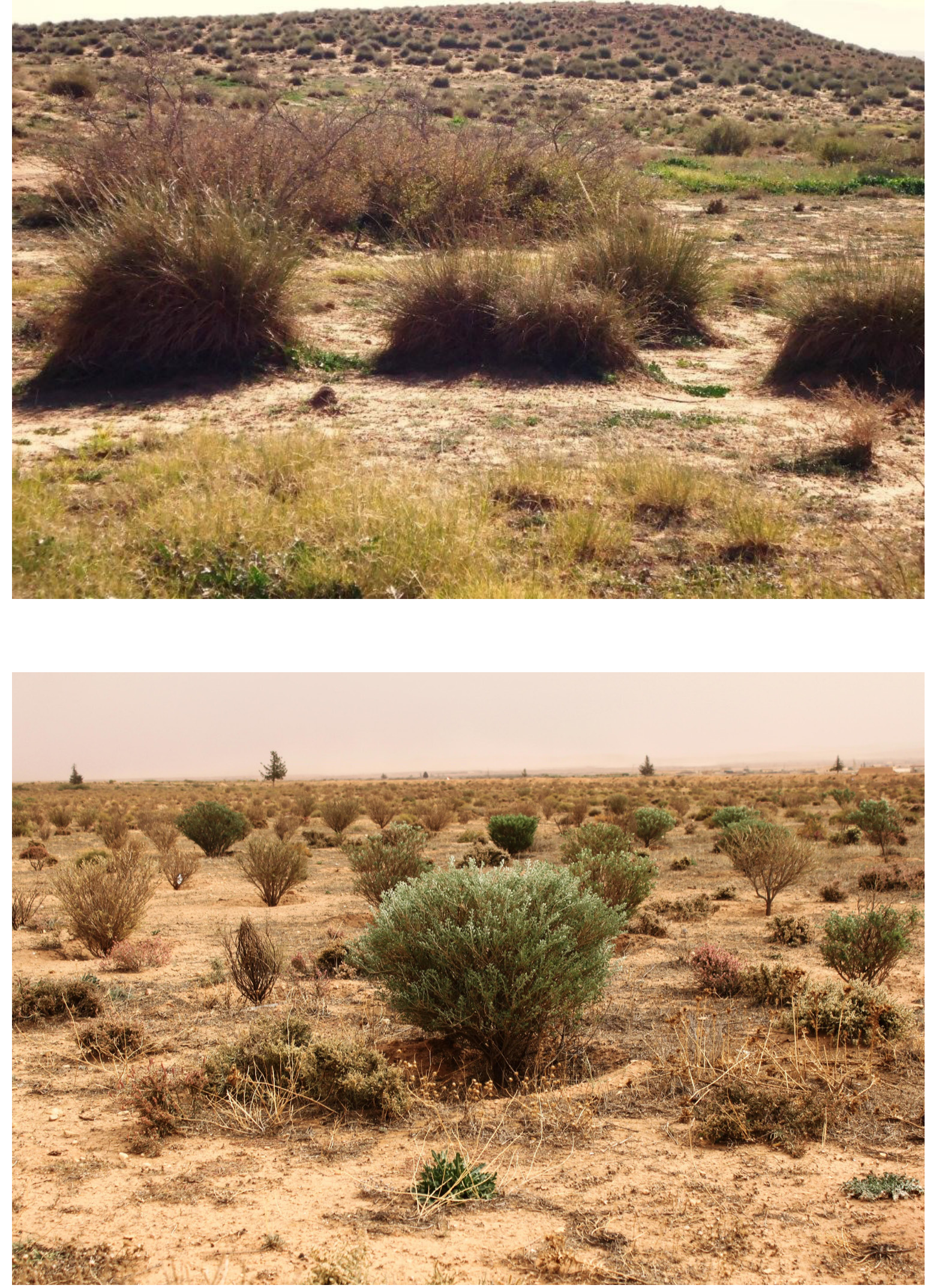

Fig. 2. The experimental area (Station T - top and Station M - bottom). 


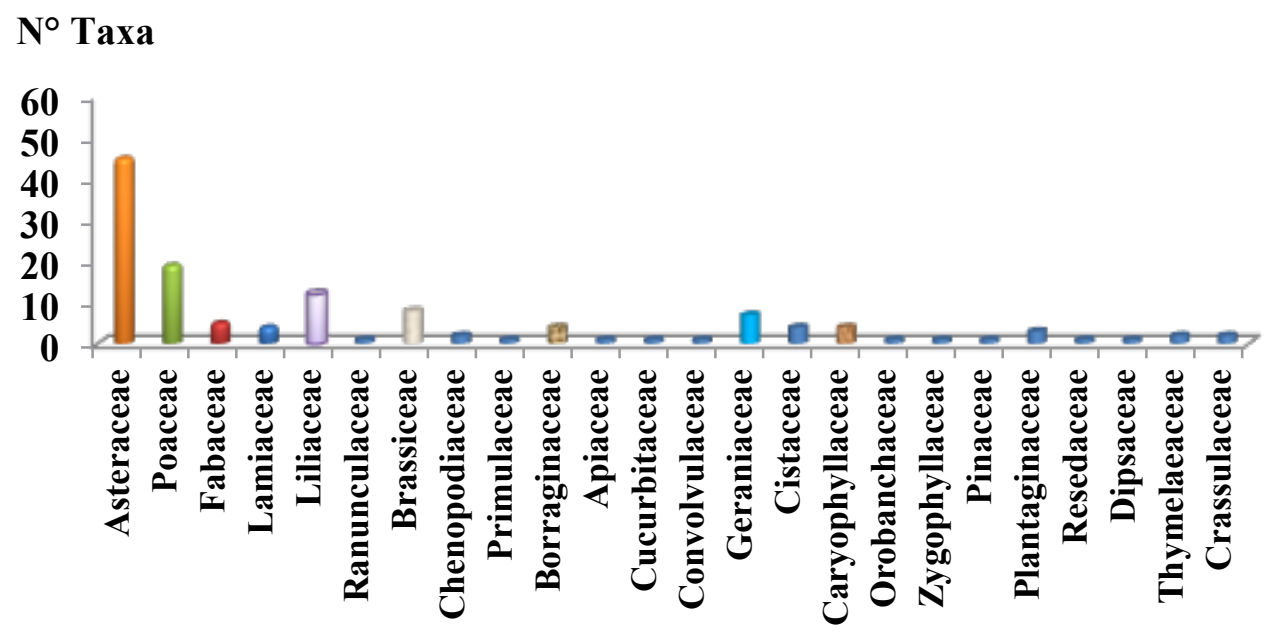

Fig. 3. The most represented families (number of taxa) of Station T.

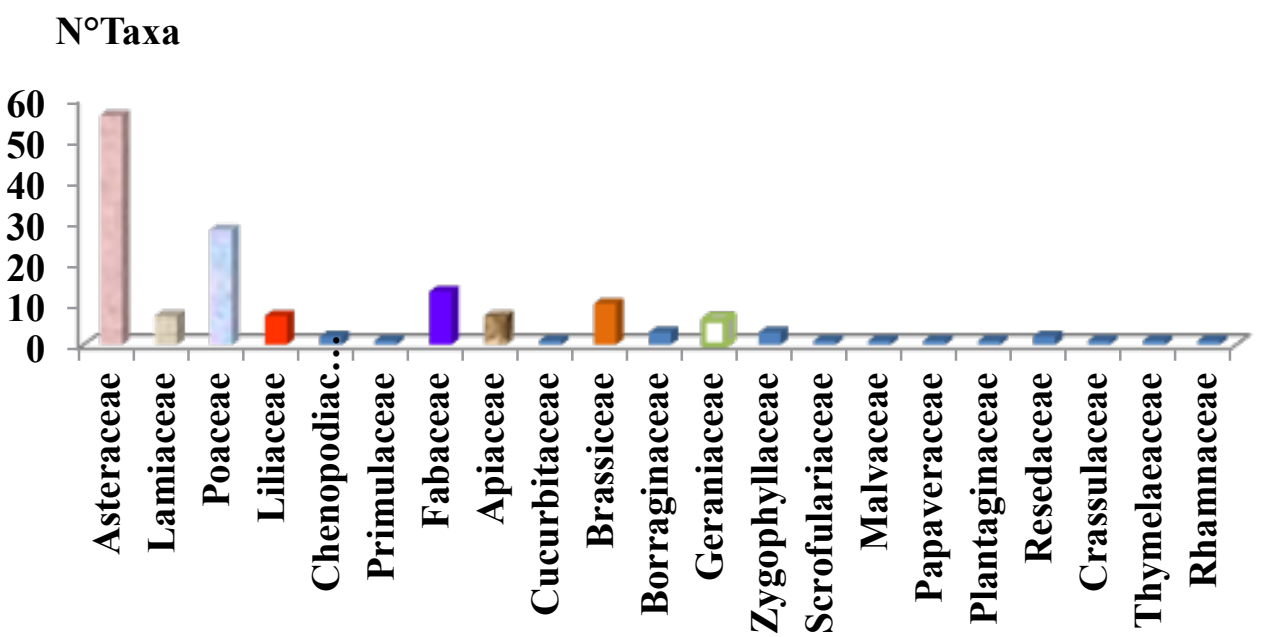

Fig. 4. The most represented families (number of taxa) of Station M.

$35^{\circ} 32^{\prime} 42.1^{\prime \prime} \mathrm{N}$. The highest point of this station is $568 \mathrm{~m}$ with a medium recovery (Fig. 2).

\section{Soil sampling and analysis method}

After characterisation of each horizon in situ to precise the apparent characters of profile was carried out (colour, length, depth, effervescence and the recovery rate) (Delaunois, 2006) at the level of the two stations also, using the chart of Munsell of colour (Munsell Soil Color Book, 2009). The 15 samples used in this study were collected from the surface horizons $(0-45 \mathrm{~cm})$. In this contribution, the analyses were conducted in the laboratory of research in Ecology and Environment, University Abderrahman Mira of Bejaia, Algeria. The soil analyses were carried out according to volume 1 of soil analyses (Petard, 1993). Each soil sample was air dried, thoroughly mixed and passed through a $2-\mathrm{mm}$ sieve. Then, all the analyses were performed in the sample. Chemical properties of the soil samples were quantified in laboratory. The $\mathrm{pH}$ was measured using a $\mathrm{pH}$ me- ter with a soil/water ratio of $1 / 2.5$. Electrical conductivity (EC) of saturation extracts was determined by a conductivity meter with a land/water ratio of $1 / 5$. Total limestone was determined by the calcimeter method of Bernard. ACCE was determined by the NH4-oxalate method (Drouineau, 1942). Gypsum (calcium sulphate, $\mathrm{CaSO}_{4} \cdot 2 \mathrm{H}_{2} \mathrm{O}$ ) content was found by acetone precipitation method. This method is a wet chemical method. It includes extraction of soil sample with an amount of water sufficient to dissolve all the gypsum present and then gypsum is precipitated with acetone. The precipitate is completely dissolved in distilled water and gypsum is obtained by measuring the EC of the solution (US Salinity Laboratory Staff, 1954).

\section{Statistical analysis}

Principal Component Analysis (PCA) is a multivariate statistical technique that uses orthogonal transformation to convert a set of correlated variables into a set of orthogonal, uncorrelated axes called principal components. Ecologists most frequently deal 
Ekológia (Bratislava) 2021: 40(4): 337-347

Table 1. Biological types of the study area

\begin{tabular}{|l|c|c|c|c|}
\hline Biological type & No. of taxa (ST) & No. of taxa (SM) & Proportion \% (ST) & Proportion \% (SM) \\
\hline Therophytes & 50 & 65 & 38 & 42 \\
\hline Hemicryptophytes & 35 & 40 & 27 & 26 \\
\hline Chamaephytes & 32 & 38 & 24 & 25 \\
\hline Phanerophytes & 8 & 6 & 6 & 4 \\
\hline Geophytes & 6 & 4 & 5 & 3 \\
\hline Total & 131 & 153 & 100 & 100 \\
\hline
\end{tabular}

Table 2. Averages of chemical analyses.

\begin{tabular}{|l|c|c|c|c|c|c|}
\hline Station & $\mathrm{pH} \mathrm{H}_{2} \mathbf{O}$ & $\mathbf{p H ~ K C l}$ & $\mathbf{C a C O}_{3}(\%)$ & $\mathbf{C A} \%$ & GYPSUM\% & EC $(\mathbf{m S} / \mathbf{c m})$ \\
\hline STH1 TC & 8.21 & 7.67 & 25 & 16 & 3 & 0.2 \\
\hline STH2 TC & 8.29 & 7.73 & 24 & 11 & 5 & 0.15 \\
\hline SMH1C & 8.35 & 7.46 & 18 & 12 & 1 & 0.098 \\
\hline SMH2C & 8.38 & 7.52 & 17 & 10 & 2 & 0.24 \\
\hline SMH3C & 8.44 & 7.72 & 26 & 17 & 4 & 0.21 \\
\hline
\end{tabular}

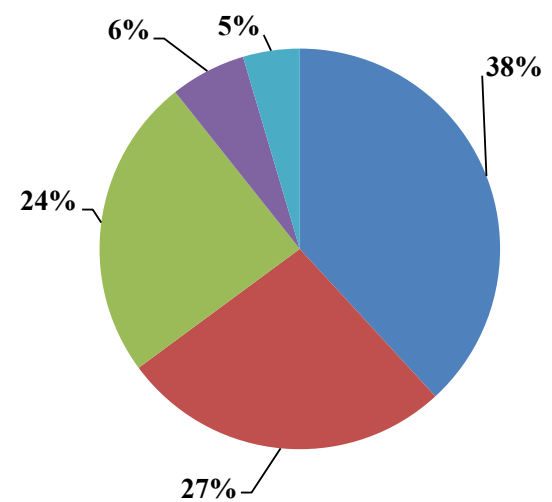

Fig. 5. Frequency of various type Station $\mathrm{T}$.
Therophytes

- Hemicryptophytes

Chamephytes

- Phanerophytes

Geophytes

.

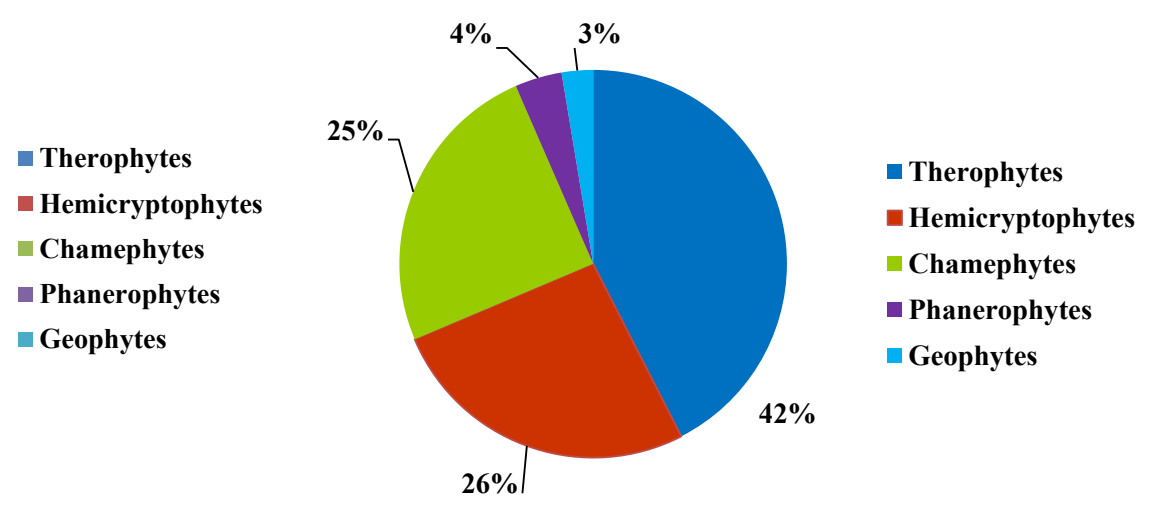

Fig. 6. Frequency of various type Station M.

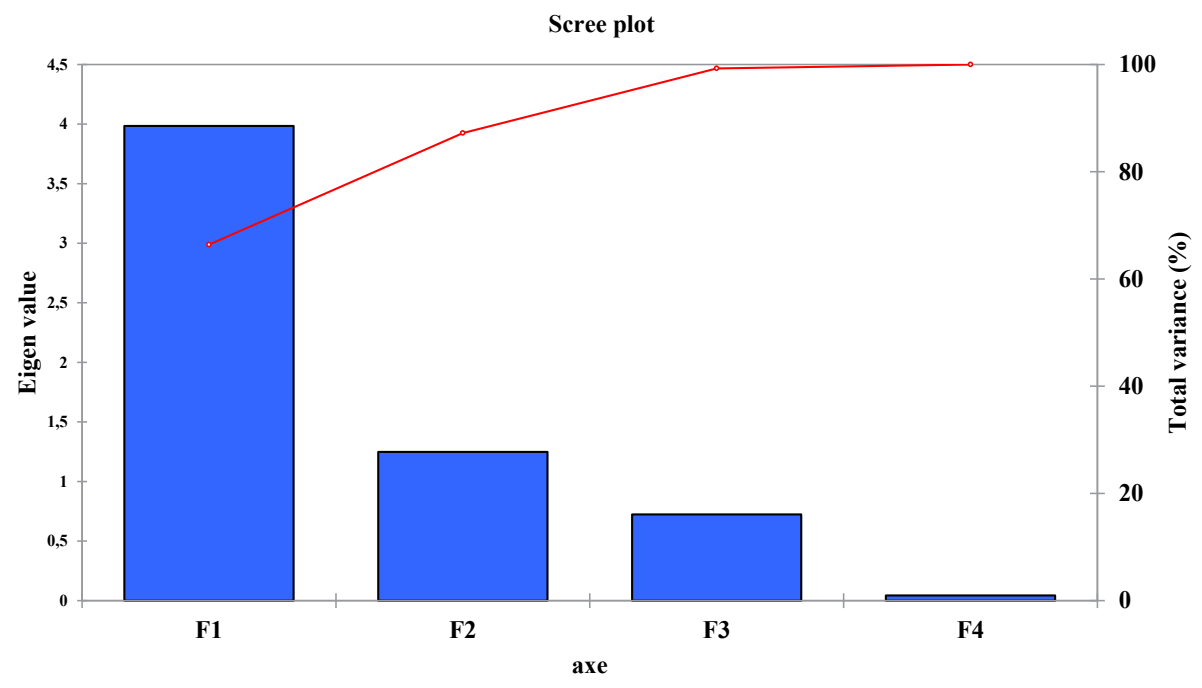

Fig. 7. Representation of the different percentages of the axes to CPA. 
with multivariate datasets. This is especially true in field ecology, and this is why PCA is an attractive and frequently used method of data ordination in ecology. PCA enables condensation of data on a multivariate phenomenon into its main, representative features by projection of the data into a two-dimensional presentation. PCA has been widely used in various fields of investigation and for different tasks. Many authors have used PCA for its main purpose, that is, to reduce strongly correlated data groups or layers. These studies concern either environmental variation (Grenouillet et al., 2011).

\section{Results and discussion}

\section{Floristic diversity}

In total, we recorded 284 taxa at the two sites. This number seems very interesting compared to that obtained by some authors who worked in the same region, including Kaabeche (2005) with 211 species and Adjabi et al. (2019) with 277 species. Our taxa belonged to 45 botanical families. The most represented families in the two stations were: Asteraceae (101 taxa), Poaceae (47 taxa), Brassicaceae (21 taxa) and Liliaceae with a total of 19 taxa. Other families like Ranunculaceae, Boraginaceae, Geraniaceae, Apiaceae and Lamiaceae were moderately represented with seven, six and five taxa, respectively. The rest of the families were poorly represented and accounted for less than four taxa (Figs 3, 4). According to Le-Houérou (2005), Compositae (=Asteraceae), Leguminoseae (=Fabaceae), Labiaceae (=Lamiaceae), Cruciferae (=Brassicaceae), Liliaceae and Umbelliferae (=Apiaceae) are the families well represented in Mediterranean regions. Endemic species are represented by 13 species; this number is more approximate to the list of endemic taxa having only a Mediterranean affinity prepared by Kaabeche (2005) inside the protected area of El-Mergueb. According to Ozenda (1991a,b), Asteraceae, Poaceae and Brassicaceae characterise the arid and semi-arid areas in the Mediterranean regions. In Algeria, some studies (KaziTani et al., 2010) highlighted the dominance of Asteraceae, Poaceae and Fabaceae in the steppe regions. This was also reported in Morocco by Fennane et al. (2012).

\section{Biological type}

The bio-morphological type of each station is also demonstrated below (Table 1). Therophytes (ST, SM: 38\%, 42\%), Hemicryptophytes (ST, SM: $27 \%, 26 \%$ ) and Chamaephytes (ST, SM: $24 \%$, $25 \%$ ) were the most represented in our experimental area in comparison to others (Figs 5, 6). According to Dajoz (2003) and Deghiche-Diab (2016), Therophytes are herbaceous species that typically appear just after a rain and when the moisture of the soil is superficial. These are the species that have difficulty to survive in a period of drought and remain in seeds form. Indeed, the richness in Therophytes represents a sign of aridity of the environment (Nègre, 1966) and the phenomenon of therophytia is considered by Daget (1980) as a strategy for avoiding adverse periods. Hemicryptophytes and Chamaephytes represent stages of degradation of grassland steppes. Their great presence can be explained by the fact that Chamaephytes are bushes that resist well to drought conditions by their foliage systems and have roots adapted to arid conditions (Le Houérou, 2005).
Table 3. Percentage of inertia explained by the first four CPA axes.

\begin{tabular}{|l|c|c|c|c|}
\hline & F1 & F2 & F3 & F4 \\
\hline Eigen value & 3,985 & 1,248 & 0,724 & 0,043 \\
\hline $\begin{array}{l}\text { Percentage } \\
\text { of the variance (\%) }\end{array}$ & 66,409 & 20,807 & 12,063 & 0,722 \\
\hline $\begin{array}{l}\text { Cumulative } \\
\text { percentage } \\
\text { of the variance (\% ) }\end{array}$ & 66,409 & 87,216 & 99,278 & 100,000 \\
\hline
\end{tabular}

F: component

Table 4. Correlations between the different edaphic variables.

\begin{tabular}{|c|c|c|c|c|}
\hline & F1 & F2 & F3 & F4 \\
\hline 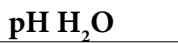 & -0.018 & 0.853 & -0.522 & -0.020 \\
\hline pH KCl & 0.964 & -0.221 & -0.052 & -0.137 \\
\hline $\mathrm{CaCO}_{3}(\%)$ & 0.973 & 0.228 & 0.001 & 0.044 \\
\hline CA (\%) & 0.991 & -0.080 & -0.096 & -0.047 \\
\hline Gypsum (\%) & 0.952 & -0.210 & -0.174 & 0.141 \\
\hline $\mathrm{CE}(\mathrm{mS} / \mathrm{cm})$ & 0.470 & 0.608 & 0.640 & 0.004 \\
\hline
\end{tabular}

Table 5. Observations of coordinates.

\begin{tabular}{|l|c|c|c|c|}
\hline Observation & F1 & F2 & F3 & F4 \\
\hline STH1 TC & 0.375 & -1.101 & 1.227 & -0.199 \\
\hline STH2 TC & 1.901 & -1.134 & -0.567 & 0.265 \\
\hline SMH1C & -3.383 & -0.424 & -0.800 & -0.065 \\
\hline SMH2C & -0.880 & 1.449 & 0.826 & 0.226 \\
\hline SMH3C & 1.988 & 1.210 & -0.685 & -0.227 \\
\hline
\end{tabular}

Table 6. Correlation between different variables (soils factors).

\begin{tabular}{|l|c|c|c|c|}
\hline Variables & F1 & F2 & F3 & F4 \\
\hline pH $\mathbf{H}_{2} \mathbf{O}$ & -0.018 & 0.853 & -0.522 & -0.020 \\
\hline pH KCl & 0.964 & -0.221 & -0.052 & -0.137 \\
\hline $\mathbf{C a C O}_{3}(\%)$ & 0.973 & 0.228 & 0.001 & 0.044 \\
\hline $\mathbf{C A}^{2}$ & 0.991 & -0.080 & -0.096 & -0.047 \\
\hline Gypsum & 0.952 & -0.210 & -0.174 & 0.141 \\
\hline $\mathbf{C E ~}(\mathbf{m S} / \mathbf{c m})$ & 0.470 & 0.608 & 0.640 & 0.004 \\
\hline
\end{tabular}

\section{Edaphic data}

The average of each parameter for the soil samples collected for 3 years is given in Table 2 . The mean $\mathrm{pH} \mathrm{H}_{2} \mathrm{O}$ values ranged between 8.21 and 8.44 , and the average $\mathrm{pH} \mathrm{KCl}$ was between 7.46 and 7.73. Soils that have a $\mathrm{pH}$ in this range are slightly alkaline soils. The mean soil salinity (EC) of soil samples used to build the models ranged from 0.098 to $0.24 \mathrm{mS} / \mathrm{cm}$, indicating that all soils in the study area are not salt affected (Aubert, 1978). The $\mathrm{CaCO}_{3}$ $\%$ content of the samples ranged between $17 \%$ and $26 \%$; these means were noted for all samples, considered moderately and highest calcareous in the third horizon of SM (Lambert, 1975); 


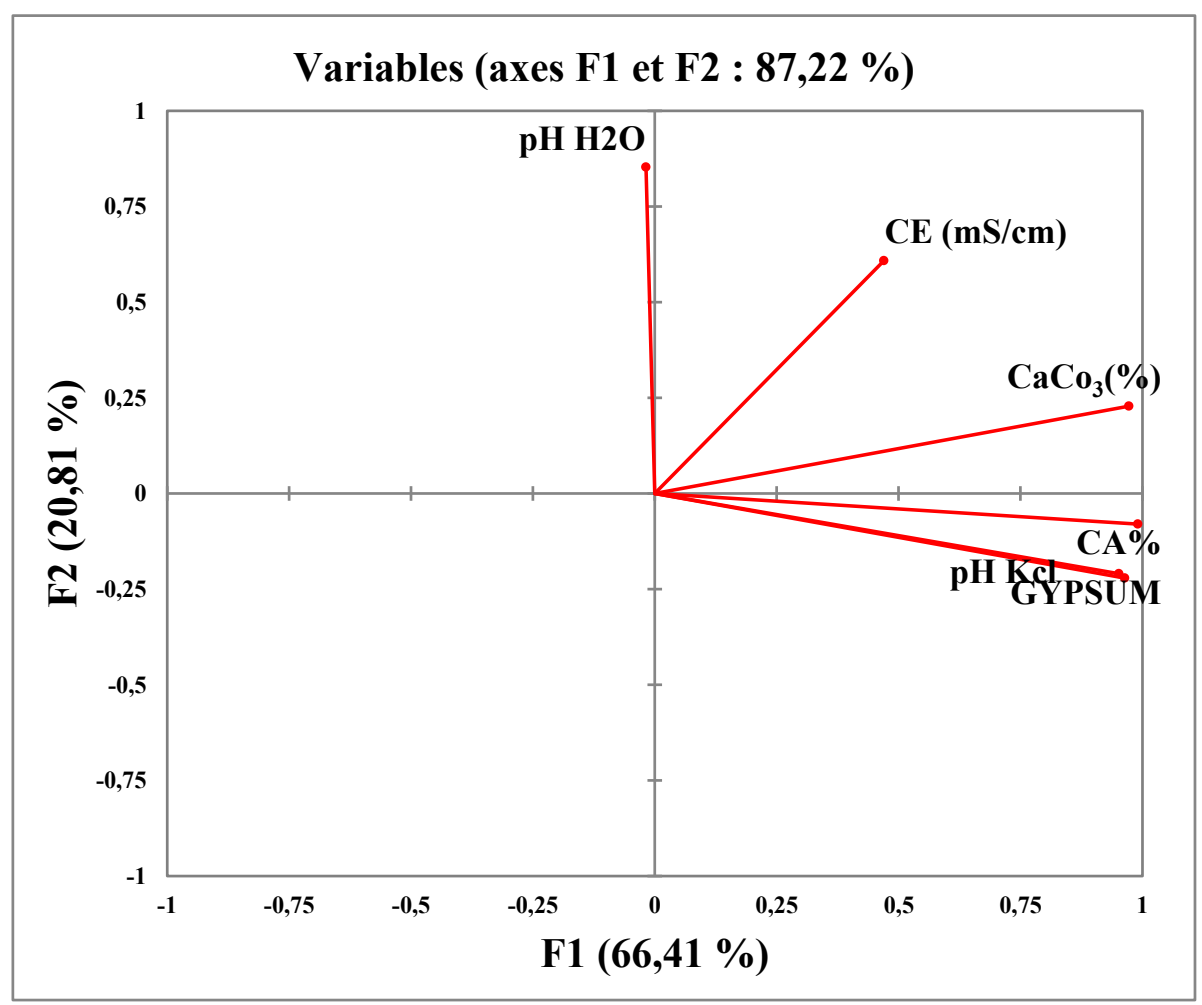

Fig. 8. Graphical presentation of the quantitative variables used for the implementation of the CAP axes 1 and 2.

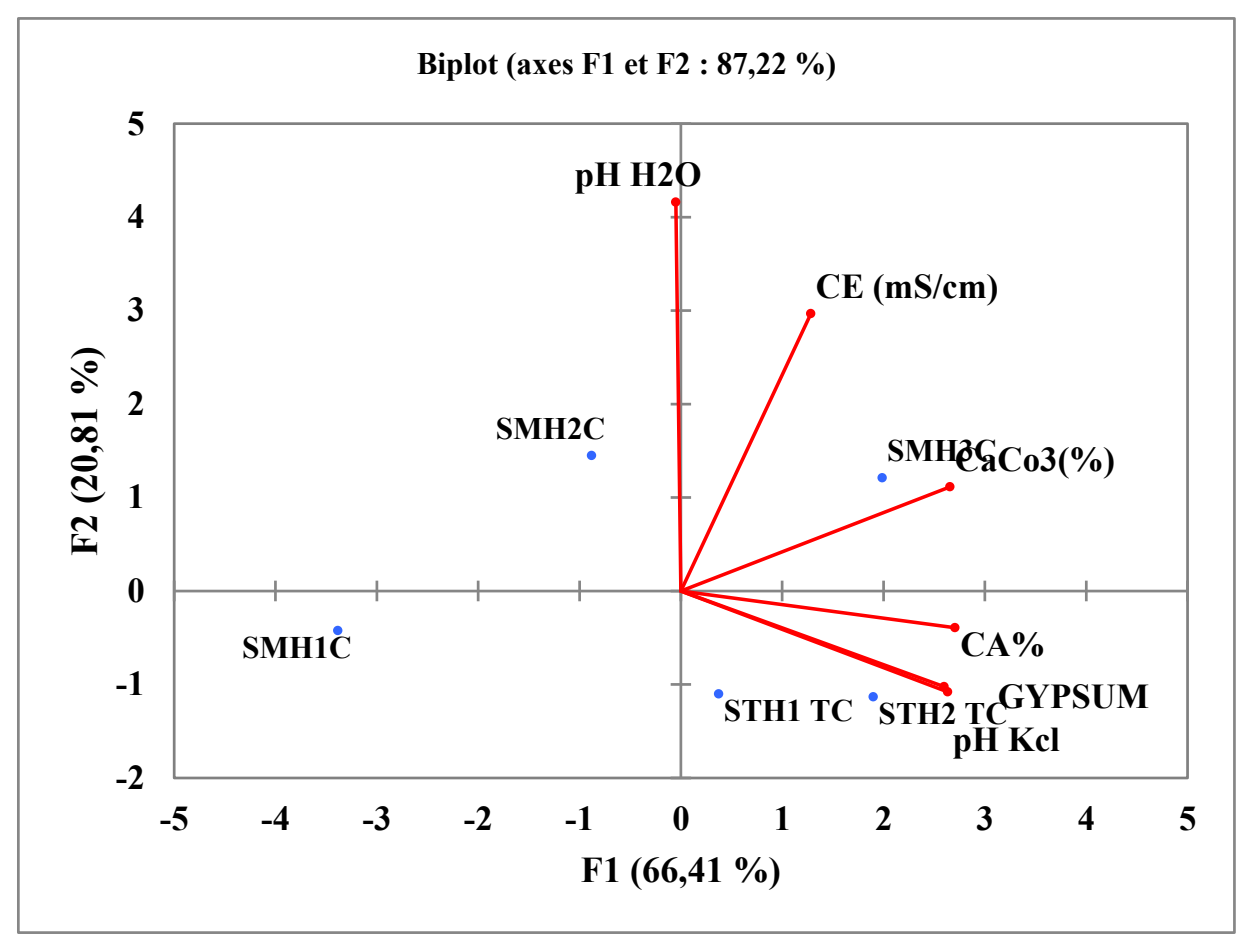

Fig. 9. Correlation between different edaphic variables of the two stations $\mathrm{T}$ and $\mathrm{M}$. 
for the active limestone, the average was from 11 to $17 \%$. The content of gypsum varied from 1 to $5 \%$ according to Barzanji (1973), who identified five classes of gypsum soils based on the aspect of 'soil-plant' the soils studied are all low gypsum $(<10 \%)$. The $\mathrm{pH}$ of our facies was alkaline; according to Franc de Ferrière (1933), North Africa (Morocco, Algeria, Tunisia) steppe region is characterised by low rainfall in winter and long summer drought causing suction of deep water to the surface, present in contrast to $\mathrm{pH}$, which is mostly alkaline, $\mathrm{pH} 7, \mathrm{pH}$. This high $\mathrm{pH}$ is, according to Mengel and Kirkby (2001), caused by an absence of ammoniacal nitrogen. A qualitatively high $\mathrm{pH}$ affects the solubility of some elements, thus influencing their absorption (Raven et al., 2010). According to Benchetrit (1956), 70-80\% of the soil of Algeria is slightly to moderately filled with limestone horizons deep in the soil versus superficially. So, it appears that the soil in the study areas is calcareous like most Algerian soils. In the Mediterranean and desert regions and, in particular, countries of the Middle East, soils containing limestone in one or several horizons are very frequent (Ruellan, 1976). Limestone can be formed by alteration of the principal rock (Ruellan, 1976) or secondary calcium carbonate precipitation (Ruellan, 1971; Duchauffour, Souchier, 1977). According to Bonneau and Souchier (1980), soils with a pH above 7 are rich in active limestone, as in the case of the soils analysed by us. Grisso et al. (1999) indicated that the sandy fraction has low EC. The soils in the study area have low salt levels; various environmental factors that lead to the dissolution of calcareous salts in the soil, being able to interact with each other, result in variation of EC of the soil. According to the FAO (1990) and Florea and Al Joumaa (1998), the high level of limestone in soil decreases and reduces the gypsum content. Halitim (1985) showed that in the arid areas of Algeria, gypsum is always posterior to calcite.

\section{Statistical data}

The PCA biplots ordination diagram is called the equilibrium contribution circle, and the radius of this circle represents a variable that would contribute equally to all dimensions of the PCA space. Therefore, for any given pair of axes, the variables that have vectors longer than this radius make a higher contribution than average and can be interpreted with confidence (Borcard, Gillet, 2018). Soil physical and chemical properties, as an important indicator of soil quality, possess not only obvious differences, but also interactions and close associations with each other, which jointly determine the quality characteristics of the soil (GarcíaRuiz et al., 2009).

\section{Choice of the number of dimensions to be studied}

The inertia of the factor axes indicates that the variables are structured (presence of correlation between variables) and suggests the number of main components to be interpreted (Husson, Pagés, 2009). The first two axes present $87.22 \%$ of the total inertia. Also, $87.22 \%$ of the total cloud variability of individuals (or variables) is represented by the first plan (Table 3, Fig. 7). This percentage is, therefore, important, and the foreground well represents the variability contained in all active datasets. Axes 3 and 4 present $12.063 \%$ and $0.722 \%$ of the total inertia, respectively, of which we have no important information. We based our findings only on two principal axes.

\section{Study of the variable cloud}

Cloud representations of variables allow visualisation correlations between variables. The PCA function provides the first graph particular to the method, that is, the circle of correlations for axes 1 and 2 (Fig. 8). The latter corresponds to a projection of the initial variables on a two-dimensional plane consisting of the first two factors (axes 1 and 2) with the active variables and additional variables (active variables in black and solid line and additional variables in red dotted lines). The fundamental result concerning variables is the table of variable factor correlations (Table 4). Present the coefficients of linear correlation between the variables who explain the position of edaphic factors studying.

Figure 8 shows that all the variables are well represented on plan 1-2. This quality of representation on the graph of variables, this good representation done because the tip of the arrow and the circle of radius 1 is so proximate. The coordinates of the variables, their qualities of representation (cosine square) and their contributions to the construction of the axes are presented in Table 4 .

Figure 5 demonstrates that the first factor (F1) is positively correlated and therefore very well represented on the graph with each the following variables: gypsum and $\mathrm{pH} \mathrm{KCl}$ with $\mathrm{CA} \%$ are very close to the circle of correlation in the same axis 1 . EC (mS/ $\mathrm{cm}$ ) is not correlated with other variables, but $\mathrm{CaCO}_{3} \%$ is highest positive and not correlated with other variables, which explains that our stations are dominated by limestone composition of soils (Fig. 5). $\mathrm{pH} \mathrm{H}_{2} \mathrm{O}$ is negatively correlated with other variables of F1 (first axis); when the soil samples have low values of edaphic variables in F2 (second axis), all soils of the two stations will be calcareous and with no salt in all axes from F1 to F4. According to Artieda and Herrero (1996), the $\mathrm{pH}$ influences the solubility of gypsum due to the attachment of $\mathrm{H}^{+}$ions to $\mathrm{SO}_{4}^{-}$anions. Solubility is high at low $\mathrm{pH}$; but this reaction can hardly occur because in all gypsum soils studied, the $\mathrm{pH}$ is always higher than 7 (Pouget, 2008).

The distribution of the chemical parameters is shown in Fig. 9 and the observations of coordinates in Table 5. Figure 9 shows that Station T, homogeneous facies, is very positively correlated with gypsum, $\mathrm{pH} \mathrm{KCl}$ and $\mathrm{CA} \%$, but Station $\mathrm{M}$, heterogeneous facies, especially the third horizon, is positively correlated with $\mathrm{CaCO}_{3} \%$. The EC is not correlated with the two stations because all our experimental sites have a low content of salt. The second horizon of Station $\mathrm{M}$ is correlated with $\mathrm{pH}$ water, but the first horizon is in the negative position of second axis (F2). This irreversible distribution of variables inside the two stations is explained by the dominance of essential parameters an related with calcareous soils ( $\mathrm{pH} \mathrm{H}_{2} \mathrm{O}$ alkaline) en relation with typology of vegetation composition (Table 6).

\section{Conclusion}

The climate is the main determinant of distribution of plant communities. Thus, the combination of a small number of bioclimatic variables predicts the distribution of vegetation types. The quality of soil is important for ecosystems because it is directly related to environmental quality and it has a direct impact on development of vegetation. Our study demonstrated that the calcareous soils dominate in a steppe ecosystem and show the high potential of vulnerably of these soils, especially when it is affected by different anthropic pressures and limited 
rainfall. Some properties inside degradable pedagogical horizons can reduce the necessary density of vegetation. Land cover of regions of El-Mergueb with their homogenous or heterogeneous facies are characterised by a high coefficient of erodability, which has been proved by many academic researchers in where they need a typical vegetation can adapted with pedological degradation under all forms of climate negative impact. The edaphic properties are the first factor that can support and protect the different phases in development of steppe plant in all seasons. The reaction between these factors is not positive all the time inside the calcareous typology of soils (alkaline) because they are exposed easily to the two categories of erosion, that is, low gypsum and salt content. has not a really effect on the vegetation in where the carbonate of calcium are the principal edaphic properties of all soils of El-Mergueb. This conclusion can be introduced and interesting of a similar category of soils inside protected area in the arid, semi-arid and sub-humid floors.

\section{Acknowledgements}

I thank the staff of: Laboratory of Ecology and Environment (LREE), Abdurrahman Mira University of Bejaia, Algeria; International Desert Research Center (IDRC), University of Tehran, Iran and Department of Sciences of Nature and Life, Faculty of Sciences, Mohamed Boudiaf University of M'sila, Algeria.

\section{References}

Adjabi, A., Sidi, H., Bounar, R. \& Naseri H.R. (2019). Floristic distribution according to the edaphic parameters of a steppe zone, case of study: the Nature Reserve "El-Mergueb" M’sila, Algeria. Ekológia (Bratislava), 38(4), 336-352. DOI: 10.2478/eko-2019-0025.

Aubert, G. (1978). Méthodes d'analyses des sols. Marseille: CRDP.

Barzanji, A. (1973). Gypsiferous soils in Iraq. PhD thesis, University of Ghent, Belgium.

Benchetrit, M. (1956). The soils of Algeria. Revue de Géographie Alpine, 44, 749-761.

Bonneau, M. \& Souchier P. (1980). Constituants et propriétés du sol. Revue Géographique des Pyrénées et du Sud-Ouest, 51(3), 376-377. https://www.persee.fr/doc/rgpso_00353221_1980_num_51_3_4589_ t1_0376_0000_2.

Borcard, D., Gille, F. \& Legendre P. (2018). Numerical ecology with R. New York: Springer. DOI: 10.1007/978-1-4419-7976-6.

Braun-Blanquet J., Roussine N., Nègre R. \& Emberger L. (1952). Les groupements végétaux de la France méditerranéenne. Paris: CNRS.

Daget, P. (1980) Sur les types biologiques en tant que stratégie adaptative (cas des thérophytes). In R. Barbault, P. Blandin \& J.A. Meyer (Eds.), Recherches d'écologie théorique, les stratégies adaptatives (pp. 89-114). Paris: Maloine.

Dajoz, R. (2003). Précis d'écologie. Paris: Dunod.

Deghiche-Diab, Na. ( 2016). Etude de la biodiversité des arthropodes et des plan spontanées dans l'agro-écosystème oasien. Magister en Sciences Agronmiques Universite Mohamed Khider Biskra.

Delaunois, A. (2006). Guide simplifié pour la description des sols. Tarn: Chambre d'Agriculture.

Del Campillo, M.C., Torrent, J. \& Looppert R.H. (1992). The reactivity of carbonates in selected soils of southern Spain. Geoderma, 52, 149-160. DOI: 10.1016/0016-7061(92)90080-Q.

Dengler, J. (2017). Phytosociology. In D. Richardson, N. Castree, M.F. Goodchild, A.I. Kubayshi, W. Liu \& R.A. Marston (Eds.), The international encyclopedia of geography: people, the Earth, environment and technology (pp. 1-6) Chichester: Willey-Blackwell. DOI: 10.1002/9781118786352.wbieg0136.

Drouineau, G. (1942). Dosage rapide du calcaire actif du sol: nouvelles données sur la séparation et la nature des fractions calcaires. Annals of Agronomy, 12, 441-450.
Duchauffour, Ph. \& Souchier B. (1977). Pédologie 1. Pédogenèse et classification. Paris: Masson.

FAO (1990). Management of gypsiferous soils. Bulletin $n^{\circ} 62$. Rome: FAO.

FAO (2013). Etat des forêts méditerranéennes 2013.

Fennane, M. \& Ibn Tattou M. (2012). Statistiques et commentaires sur l'inventaire actuel de la flore vasculaire du Maroc. Bulletin de l'Institut Scientifique, Rabat, section Sciences de la Vie, 34(1), 1-9.

Florea, N. \& Al-Joumaa Kh.Fer (1998). Genesis and classification of gypsiferious soils of the midlle euphrates floodplain. Syria. Geoderma, 87(1-2), 67-85. DOI: 10.1016/S0016-7061(98)00066-4.

Franc de Ferrière, J. (1933). Les zones de $\mathrm{pH}$ des sols. Bulletin de l'Association de Géographes Français, 69(10e), 74-78. DOI: 10.3406/bagf.1933.6626.

Franc de Ferrière, J. \& Jacques-Félix H. (1936). Le marais à Raphia gracilis de Guinée Française. Valeur et utilisation agricoles. Journal d’Agriculture Traditionnelle et de Botanique Appliquée, 174, 105-123.

García-Ruiz, R., Ochoa, V., Vinegla, B., Hinojosa, M.B., Pena-Santiago, R., Liebanas, G., Linares, J.C. \& Carreira J.A. (2009). Soil enzymes, nematode community and selected physico-chemical properties as soil quality indicators in organic and conventional olive oil farming: Influence of seasonality and site features. Appl. Soil Ecol., 41, 305-314. DOI: 10.1016/j.apsoil.2008.12.004.

Ghaouaci, S., Amarouayache, M., Sinev, A.Y., Korovchinsky, N.M. \& Kotov A.A. (2018). An annotated checklist of the Algerian Cladocera (Crustacea: Branchiopoda). Zootaxa, 4377, 412-430. DOI: 10.11646/ zootaxa.4377.3.5.

Gratzlfeld, J. (2003). Extractive industries in arid and semi-arid zones: Environmental planning and management. Gland: IUCN.

Grenouillet, G., Buisson, L., Casajus, N. \& Lek S. (2011). Ensemble modelling of species distribution: the effects of geographical and environmental ranges. Ecography, 34, 9-17. DOI: 10.1111/j.1600-0587.2010.06152.x.

Grisso, R., Wysor, W.G., Holshouser, D. \& Thomason W. (1999). Precision farming tools: Soil electrical conductivity. Virginia: Polytechnic Institute and State University.

Hadjab, M., Benkheira, A. \& Chicouche A. (2016). La préservation de la réserve d'El -Mergueb (M'sila -Algérie). Analele Universitatis Bucuresti, Seria Geografie, 21-40.

Halitim, A. (1985). Contribution à létude des sols des zones arides (Hautes plaines steppiques de l'Algérie). Morphologie, distribution et rôle des sels dans la genèse et le comportement des sols. Thèse doctorat, Univ. Renne.

Husson, F., Lé, S. \& Pagès J. (2009). Analyse de données avec R. Pratique de la Staistique. France: Presse Univérsitaires de RENNES.

Ioualalen, G. ( 2012). Analyse multi-temporelle de la végétation de la reserve naturelle d'El Mergueb (M'sila) par application des techniques géomatique. Ecole Nationale Superieure Agronomique.

IPCC (2007). Climate Change 2007: Synthesis Report, Contribution of Working Groups I, II and III to the Fourth Assessment Report of the Intergovernmental Panel on Climate Change. Geneva: IPCC.

Janišová, M. (2005). Vegetation-environment relationships in dry calcareous grassland. Ekológia (Bratislava), 24(1), 25-44.

Kaabeche, M. (2005). Management plan of the site of El- Mergueb, hydrogeology, project DGF.NUD-ALG/G 35. In the national program of classification of the protected areas in Algeria.

KaziTani, Ch., Le Bourgeois, T. \& Munoz F. ( 2010). Aspects floristiques des adventices du domaine phytogéographique oranais (Nord-Ouest Algérien) et persistance despèces rares et endémiques. Flora Mediterannea, 20, 29-46.

Lambert, J. (1975). Analyse des sols et des végétaux. Laboratoire d’Agriculture.

Lavorel, S., Canadell, J., Rambla, S. \& Terradas J. (1998). Mediterranean terrestrial ecosystems: research priorities on global change effects. Glob. Ecol. Biogeogr., 7, 157-166. DOI: 10.2307/2997371.

Le Houérou, H.N. (2005). Atlas of climatic diagrams for the isoclimatic Mediterranean regions. Montpellier: Copymania.

Maestre, F.T. \& Cortina J. (2002). Spatial pattern of soil properties and vegetation in a Mediterranean semi-arid steppe. Plant Soil, 241, 279-291. DOI: 10.1023/A:1016172308462.

Maestre, F.T., Eldridge, D.J., Soliveres, S., Kéfi, S., Delgado-Baquerizo, M. Bowker, M.A., García-Paacios, P., Gaitán, J., Gallardo, A., Lázaro, R. \& Berdugo M. (2016). Structure and functioning of dryland ecosystems in a changing world. Annu. Rev. Ecol. Evol. Syst., 47, 215-237. DOI: 10.1146/annurev-ecolsys-121415-032311.

Mengel, K. \& Kirkby E.A. (2001). Principles of plant nutrition. Dordrecht: Kluwer Academic Publishers. 
Miara, M.D., Bendif, H., Ait Hammou, M. \& Teixidor Toneu I. (2018). Eth nobotanical survey of medicinal plants used by nomadic peoples in the Algerian steppe. J. Ethnopharmacology, 219, 248-256. DOI: 10.1016/j. jep.2018.03.011.

Miranda, J.D., Armas, C., Padilla, F.M. \& Pugnaire F.I. (2011). Climatic change and rainfall patterns: Effects on semi-arid plant communities of the Iberian Southeast. J. Arid Environ., 75, 1302-1309. DOI: 10.1016/j. jaridenv.2011.04.022.

Munsell Soil Color Book (2009). Year revised. 2015 production. Grand Rapids: Munsell ColorX-Rite.

Nedjraoui, D. \& Bédrani S. (2008). La désertification dans les steppes algériennes: causes, impacts et actions de lutte. Revue Vertigo, 8(1), http://vertigo.revues.org/5375.

Nègre, R. (1966). Les thérophytes. Bulletin de la Société Botanique de France, 113(Suppl.2), 92-108. DOI: 10.1080/00378941.1966.10838477.

Ozenda, P. (1958). Flore du Sahara septentrional et central. Centre National de la Recherche Scientifique.

Ozenda, P. (1991a). Flore du Sahara. Paris: C.N.R.S.

Ozenda, P. (1991b). Les relations biogéographiques des montagnes sahariennes avec la région méditerranéenne. Revue Degéographie Alpine, 79(1), 43-53. DOI: $10.3406 /$ rga.1991.3585

Petard, J. (1993). Les méthodes d'analyse. Vol. 1. Analyses de sols. Paris: Orstom.

Plan de gestion du site de Mergueb (2005).W i l a y a d e M' s i 1 a « Conservation de la biodiversité et gestion durable des ressources naturelles des sites de Mergueb (M'sila), Oglet ed daira (Naama) et Taghit (Bechar).

Pouget, M. (2008). Archives environnementales sur l'Algérie steppique (1968-1975). Paris: IRD.

Quezel, C. \& Santa P. (1962-1963). Nouvelle flore de l’Algérie et des régions désertiques méridionales. Paris: C.N.R.S.
Ramirez, N., Dezzeo, N. \& Chacon N. (2007). Floristic composition, plant species abundance, and soil properties of montane savannas in the Gran Sabana, Venezuela. Flora, 202(4), 316-327. DOI: 10.1016/j.flora.2006.07.005.

Rasha, E.A. (2005). The relation between active calcium carbonate and some properties of calcareous soils in North Africa. M. Sc. Thesis Cairo, Univ. of Ins. of African Res. and Studies Dep. of Natural Resources.

Raven, P.H., Berg, L.R. \& Hassenzahl D.M. (2010). Environment. USA: John Wiley \& Sons

Ruellan, A. (1971) . Les sols de la base moulouya (Maroc oriental). Paris: Orstom.

Ruellan, A. (1976). Morphologie et répartition des sols calcaires dans les régions méditerranéennes et désertiques. Annales de l.INA, 6(1), 11-39.

Steven, B. (2017). An introduction to arid soils and their biology chapter. In The biology of arid soils (pp.1-14). DOI: 10.1515/9783110419047-001.

Taalab, A.S, Ageeb, G-W, Hanan, S. Siam \& Safaa A. Mahmoud (2019). Some characteristics of calcareous soils. A review. Middle East Journal of Agriculture Research, 8(1), 96-105.

Tálamo, A., Lopez de Casenave, J. \& Caziani S.M. (2012). Components of woody plant diversity in semi-arid Chaco forests with heterogeneous land use and disturbance histories. J. Arid Environ., 85, 79-85. DOI: 10.1016/j.jaridenv.2012.05.008.

US Salinity Laboratory Staff (1954). Diagnosis and improvement of saline and alkali soils. Washington: US Government Printing Office.

Uso-Domenech, J.L., Villacampa-Esteve, Y., Stübing-Martinez, G., Karjalainen, T. \& Ramo M.P. (1995). MARIOLA: a model for calculating the response of Mediterranean bush ecosystem to climatic variations. Ecol. Model., 80, 113-129. DOI: 10.1016/0304-3800(94)00052-J.

Yaalon, D. H. (1999). Soils in the Mediterranean region: what makes them different? Catena, 28(3-4), 157-169. DOI: 10.1016/S0341-8162(96)00035-5. 